\title{
Molecular Markers as Prognostic Factors in DCIS and Small Invasive Breast Cancers
}

\author{
Molekulare Marker als Prognosefaktoren \\ für DCIS und invasive T1a Mammakarzinome
}

Authors

Affiliations
N. Sänger ${ }^{1}$, K. Engels ${ }^{2}$, A. Graf ${ }^{1}$, E. Ruckhäberle ${ }^{3}$, K. E. Effenberger ${ }^{4}$, T. Fehm ${ }^{3}$, U. Holtrich ${ }^{1}$, S. Becker, T. Karn ${ }^{1}$

${ }^{1}$ Dept. of Gynecology and Obstetrics, Goethe University Frankfurt, Frankfurt

2 Zentrum für Pathologie, Zytologie und Molekularpathologie, Neuss

${ }^{3}$ Department of Gynecology and Obstetrics, University Hospital Düsseldorf, Heinrich Heine Universität Düsseldorf, Düsseldorf

${ }^{4}$ University Medical Center Hamburg-Eppendorf, Hamburg

\author{
Key words \\ - breast cancer \\ - DCIS \\ prognosis \\ - molecular subtypes \\ - ER status \\ Schlüsselwörter \\ - Brustkrebs \\ - DCIS \\ - Prognose \\ molekulare Subtypen \\ - Östrogenrezeptor-Status
}

\section{received 28.7.2014 \\ revised 11.8.2014 \\ accepted 18.8.2014}

Bibliography

DOI http://dx.doi.org/

10.1055/s-0034-1383033

Geburtsh Frauenheilk 2014; 74:

1016-1022 @ Georg Thieme

Verlag KG Stuttgart · New York .

ISSN 0016-5751

\author{
Correspondence \\ Dr. Thomas Karn \\ Goethe University \\ Dept. of Gynecology \\ and Obstetrics \\ Theodor-Stern-Kai 7 \\ 60596 Frankfurt \\ t.karn@em.uni-frankfurt.de
}

\section{Abstract \\ $\nabla$}

Ductal carcinoma in situ (DCIS) accounts for up to half of screen-detected breast cancers and thus constitutes a major public health problem. Despite effective current treatment many patients with DCIS are either over- or undertreated because of the paucity of precise models to predict recurrence or progression. The combination of clinical and molecular factors as already applied for invasive disease may help to build such models also for DCIS. We compared 53 DCIS (36.6\%) and 92 (63.4\%) invasive breast cancer cases and found no significant differences in age, receptor status of ER, PR, and HER2, and the use of radiotherapy. Interestingly, the proportion of disseminated tumor cells (DTC) did also not significantly differ between DCIS and invasive cases $(p=0.57)$. A negative PR status was associated with the detection of DTCs $(p=0.026)$. We then compared relationships of clinical parameters and biomarkers with patients' prognosis in 43 DCIS and 40 small invasive tumors $\leq 5 \mathrm{~mm}$ (T1a). ER negativity was associated with shorter relapse free survival in the complete cohort $(p=0.004)$ and showed a trend in both subgroups $(p=0.053$ for DCIS and $\mathrm{p}=0.046$ for T1a, respectively). In conclusion, we found markedly similar properties of both DCIS and small invasive breast cancers with respect to the distribution of several parameters as well as to the prognostic value of biomarkers. DCIS with a luminal phenotype seem to be characterized by a favourable prognosis.

\section{Zusammenfassung \\ $\nabla$}

Das duktale Carcinoma in situ (DCIS) ist aufgrund seiner durch das Mammografie-Screening stark angestiegenen Häufigkeit in den letzten Dekaden deutlicher ins Blickfeld von Forschung und Praxis gerückt. Trotz effektiver Behandlung stellt sich für viele Patientinnen die Frage einer Über- oder Untertherapie, da sich der Verlauf der Erkrankung individuell nicht vorhersagen lässt. Eine Kombination von klinischen und molekularen Parametern, wie sie bereits vielfach für das invasive Mammakarzinom angewandt wird, könnte hier möglicherweise helfen, entsprechende Prädiktoren zu entwickeln. Bei einem Vergleich von 53 DCIS (36,6\%) und 92 (63,4\%) invasiven Mammakarzinomen bezüglich klinischer und molekularer Parameter fanden wir keine signifikanten Unterschiede bez. Alter, Hormonrezepor- und HER2Status sowie dem Einsatz adjuvanter Bestrahlung. Interessanterweise unterschied sich auch die Häufigkeit der Detektion disseminierter Tumorzellen (DTZ) nicht signifikant zwischen DCIS und invasiven Fällen $(p=0,57)$. Ein negativer Progesteronrezeptor-Status war mit dem DTZ-Nachweis assoziiert $(p=0,026)$. Untersucht wurde ebenfalls der Zusammenhang von klinischen Parametern und Biomarkern mit der Prognose bei 43 DCIS und 40 invasiven T1a-Karzinomen. Negativität für den Östrogenrezeptor zeigte hierbei einen signifikanten Zusammenhang zu einem kürzeren krankheitsfreien Intervall in der Gesamtkohorte $(p=0,004)$ und einen Trend in beiden Subgruppen ( $p=0,053$ bei DCIS bzw. $p=0,046$ bei T1a). Zusammenfassend fanden wir sehr ähnliche Charakteristika bez. der Verteilung verschiedener Parameter und des prognostischen Werts von Biomarkern sowohl bei DCIS als auch invasiven Karzinomen. DCIS mit einem luminalen Phänotyp scheint durch eine günstigere Prognose gekennzeichnet zu sein. 


\section{Introduction}

Before the advent of screening, DCIS represented only $2-5 \%$ of symptomatic breast cancers; at present it accounts for approximately $20-25 \%$ of all and up to half of screen-detected breast cancers $[1,2]$. DCIS is defined as local disease involving proliferation of abnormal epithelial cells limited by the basement membrane without stromal invasion and represents a non-obligate precursor of invasive breast cancer (IBC). Not all DCIS progress to invasive disease if untreated but the estimated range is 25$50 \%[1,3,4]$. Thus, once DCIS has been detected, treatment is obligatory although the majority of women with DCIS are not destined to recur let alone die of their disease [3]. Moreover, present technologies do not allow accurate risk stratification such that intensity of treatment can be tailored to risk of recurrence and progression to invasive disease [1]. Therefore many women are either over- or undertreated and there is pressing need for novel diagnostic approaches to improve risk stratification $[3,5]$. Conventional risk factors for recurrence in DCIS patients include margin status, young age, nuclear grade, as well as family history. However, traditional prognostic factors alone or in combination (e.g the Van Nuys Prognostic Index or nomograms) have yet failed to provide the necessary precision needed for therapeutic decision making. Several attempts have been started to include molecular factors in diagnosis similar to the approaches applied for invasive disease. Although there have been efforts to develop clinical or molecular tests [6] to predict which patients are likely to relapse with invasive disease, currently no validated test is available with demonstrated clinical utility to identify this population $[3,4]$. Invasive breast cancer encompasses at least four major molecular subtypes which differ by their expression of estrogen (ER) and progesterone (PR) receptors, HER2, and the proliferative status of the tumor [7-9]. This gene expression based subtype classification is also supported by whole genome sequencing studies $[10,11]$. Similar approaches were already applied to adopt these molecular subtypes also for DCIS $[12,13]$ but the numbers of samples analyzed are still very small.

In the present study we performed a comparison of DCIS with invasive breast cancer in two ways. First, we analyzed differences in clinical and molecular parameters between cohorts of DCIS and invasive cancers. Second, we compared the prognostic value of different parameters and biomarkers in cohorts of DCIS and small invasive cancer (T1a). Our results support molecular subtyping of DCIS as profitable step towards prognostic and predictive models for DCIS recurrence.

\section{Materials and Methods \\ $\nabla$}

\section{Patients and samples}

The study cohort included 145 patients undergoing surgical resection for either DCIS or invasive breast cancer between January 2004 and November 2011 at the Breast Unit of the Goethe University Hospital in Frankfurt. 90 patients participated in a study on the detection of disseminated tumor cells (61 cases of invasive breast cancer and 29 cases of DCIS). The number of samples with DCIS and T1a tumors was further increased by including a second set of 55 consecutive patients ( 24 with DCIS and 31 with T1a tumors, respectively) for which no data on tumor cell dissemination was available. Formalin-fixed, paraffin-embedded (FFPE) tissue samples were obtained from the Senckenberg's Institute of
Table 1 Clinical characteristics of the full cohort.

\begin{tabular}{|c|c|c|c|}
\hline Parameter & & Total & $\begin{array}{l}\text { Per- } \\
\text { cent }\end{array}$ \\
\hline \multirow[t]{4}{*}{ Age } & Age $>50$ & 101 & 71.1 \\
\hline & Age $\leq 50$ & 41 & 28.9 \\
\hline & n.a. & 3 & \\
\hline & Median age & 57 & \\
\hline \multirow[t]{5}{*}{ Tstatus } & DCIS & 53 & 36.6 \\
\hline & $\mathrm{T} 1$ & 67 & 46.2 \\
\hline & $\mathrm{T} 2$ & 15 & 10.3 \\
\hline & T3 & 7 & 4.8 \\
\hline & T4 & 3 & 2.1 \\
\hline \multirow[t]{3}{*}{ Lymph node status } & LNN & 104 & 83.9 \\
\hline & $\mathrm{N}+$ & 20 & 16.1 \\
\hline & n.a. & 21 & \\
\hline \multirow[t]{2}{*}{ Primary metastasis } & M0 & 138 & 95.2 \\
\hline & M1 & 7 & 4.8 \\
\hline \multirow[t]{4}{*}{ Grade* } & $\operatorname{Low}(\mathrm{G} 1)$ & 13 & 9.7 \\
\hline & Intermediate (G2) & 59 & 44.0 \\
\hline & $\operatorname{High}(G 3)$ & 61 & 45.5 \\
\hline & n.a. & 12 & \\
\hline \multirow[t]{3}{*}{ ER status } & Positive & 92 & 64.8 \\
\hline & Negative & 50 & 35.2 \\
\hline & n.a. & 3 & \\
\hline \multirow[t]{3}{*}{ PR status } & Positive & 72 & 51.1 \\
\hline & Negative & 69 & 48.9 \\
\hline & n.a. & 4 & \\
\hline \multirow[t]{3}{*}{ HER2 status } & Positive & 45 & 36.3 \\
\hline & Negative & 79 & 63.7 \\
\hline & n.a. & 21 & \\
\hline \multirow[t]{5}{*}{ Molecular Subtype } & TNBC & 18 & 14.6 \\
\hline & HER2 & 24 & 19.5 \\
\hline & Luminal & 61 & 49.6 \\
\hline & Luminal-HER2 & 20 & 16.3 \\
\hline & n.a. & 22 & \\
\hline \multirow[t]{3}{*}{ DTC detection } & Positive & 17 & 21.2 \\
\hline & Negative & 63 & 78.8 \\
\hline & n.a. & 65 & \\
\hline \multirow[t]{3}{*}{ Adjuvant radiotherapy } & Yes & 45 & 39.8 \\
\hline & No & 68 & 60.2 \\
\hline & n.a. & 32 & \\
\hline \multirow[t]{3}{*}{ Adjuvant chemotherapy } & Yes & 20 & 17.7 \\
\hline & No & 93 & 82.3 \\
\hline & n.a. & 32 & \\
\hline \multirow[t]{3}{*}{ Adjuvant endocrine therapy } & Yes & 51 & 45.1 \\
\hline & No & 62 & 54.9 \\
\hline & n.a. & 32 & \\
\hline \multirow[t]{3}{*}{ Adjuvant trastuzumab treatment } & Yes & 10 & 8.8 \\
\hline & No & 103 & 91.2 \\
\hline & n.a. & 32 & \\
\hline
\end{tabular}

* Nottingham histological grade for invasive cancer or nuclear grade for DCIS according to CAP guidelines

Pathology, University Frankfurt/Main, Germany. Clinical and pathological factors were evaluated by reviewing medical charts and pathology records. The Local Research Ethics Committees approved studies of human tissue and samples were processed anonymously.

\section{Histopathological evaluation} and immunohistochemistry

Routine histopathology sections stained with haematoxylin-eo$\sin (\mathrm{HE})$ were used for primary diagnosis and second reviewing (KE). Diagnosis and grading was performed according to current 
Table 2 Comparison of clinical parameters and biomarkers between DCIS and invasive breast cancers.

\begin{tabular}{|c|c|c|c|c|c|c|c|c|c|c|c|c|c|c|}
\hline \multicolumn{2}{|l|}{ Parameter } & \multicolumn{2}{|l|}{ Total } & \multicolumn{2}{|c|}{ DCIS } & \multicolumn{2}{|c|}{ T1a } & \multicolumn{2}{|c|}{ T1b-T4 } & \multicolumn{2}{|c|}{ T1-T4 } & \multirow{2}{*}{$\begin{array}{l}\text { p-value } \\
\text { DCIS vs. } \\
\text { T1a }\end{array}$} & \multirow{2}{*}{$\begin{array}{l}\text { p-value } \\
\text { 3- } \\
\text { groups }\end{array}$} & $\begin{array}{l}\text { p-value } \\
\text { DCIS vs. } \\
\text { T1-T4 }\end{array}$ \\
\hline \multirow[t]{2}{*}{ Age } & Age $\leq 50$ & 41 & $28.9 \%$ & 12 & $23.1 \%$ & 13 & $30.2 \%$ & 16 & $34.0 \%$ & 29 & $32.2 \%$ & & & \\
\hline & Age $>50$ & 101 & $71.1 \%$ & 40 & $76.9 \%$ & 30 & $69.8 \%$ & 31 & $66.0 \%$ & 61 & $67.8 \%$ & 0.49 & 0.47 & 0.34 \\
\hline \multirow[t]{3}{*}{ Grade* } & Low (G1) & 13 & $9.8 \%$ & 4 & $8.3 \%$ & 5 & $13.9 \%$ & 4 & $8.2 \%$ & 9 & $10.6 \%$ & & & \\
\hline & $\begin{array}{l}\text { Inter- } \\
\text { mediate } \\
\text { (G2) }\end{array}$ & 59 & $44.4 \%$ & 11 & $22.9 \%$ & 24 & $66.7 \%$ & 24 & $49.0 \%$ & 48 & $56.5 \%$ & & & \\
\hline & $\begin{array}{l}\text { High } \\
\text { (G3) }\end{array}$ & 61 & $45.9 \%$ & 33 & $68.8 \%$ & 7 & $19.4 \%$ & 21 & $42.9 \%$ & 28 & $32.9 \%$ & $\begin{array}{l}{[<0.001]} \\
*\end{array}$ & $\begin{array}{l}{[<0.001]} \\
*\end{array}$ & $\begin{array}{l}{[<0.001]} \\
*\end{array}$ \\
\hline \multirow{2}{*}{$\begin{array}{l}\text { HER2 } \\
\text { status }\end{array}$} & Negative & 79 & $63.7 \%$ & 20 & $60.6 \%$ & 22 & $52.4 \%$ & 37 & $75.5 \%$ & 59 & $64.8 \%$ & & & \\
\hline & Positive & 45 & $36.3 \%$ & 13 & $39.4 \%$ & 20 & $47.6 \%$ & 12 & $24.5 \%$ & 32 & $35.2 \%$ & 0.49 & 0.067 & 0.68 \\
\hline \multirow{2}{*}{$\begin{array}{l}\text { ER } \\
\text { status }\end{array}$} & Negative & 50 & $35.2 \%$ & 18 & $36.0 \%$ & 20 & $46.5 \%$ & 12 & $24.5 \%$ & 32 & $34.8 \%$ & & & \\
\hline & Positive & 92 & $64.8 \%$ & 32 & $64.0 \%$ & 23 & $53.5 \%$ & 37 & $75.5 \%$ & 60 & $65.2 \%$ & 0.40 & 0.087 & 1.0 \\
\hline \multirow{2}{*}{$\begin{array}{l}\text { PR } \\
\text { status }\end{array}$} & Negative & 69 & $48.9 \%$ & 20 & $40.8 \%$ & 25 & $58.1 \%$ & 24 & $49.0 \%$ & 49 & $53.3 \%$ & & & \\
\hline & Positive & 72 & $51.1 \%$ & 24 & $59.2 \%$ & 18 & $41.9 \%$ & 25 & $51.0 \%$ & 43 & $46.7 \%$ & 0.14 & 0.25 & 0.22 \\
\hline \multirow{4}{*}{$\begin{array}{l}\text { Molecu- } \\
\text { lar sub- } \\
\text { type }\end{array}$} & TNBC & 18 & $14.6 \%$ & 6 & $18.8 \%$ & 4 & $9.5 \%$ & 8 & $16.3 \%$ & 12 & $13.2 \%$ & & & \\
\hline & HER2 & 24 & $19.5 \%$ & 4 & $12.5 \%$ & 16 & $38.1 \%$ & 4 & $8.2 \%$ & 20 & $22.0 \%$ & & & \\
\hline & Luminal & 61 & $49.6 \%$ & 14 & $43.8 \%$ & 18 & $42.9 \%$ & 29 & $59.2 \%$ & 47 & $51.6 \%$ & & & \\
\hline & $\begin{array}{l}\text { Luminal- } \\
\text { HER2 }\end{array}$ & 20 & $16.3 \%$ & 8 & $25.0 \%$ & 4 & $9.5 \%$ & 8 & $16.3 \%$ & 12 & $13.2 \%$ & 0.041 & 0.010 & 0.27 \\
\hline \multirow{2}{*}{$\begin{array}{l}\text { DTC de- } \\
\text { tection }\end{array}$} & Negative & 63 & $78.8 \%$ & 18 & $75.0 \%$ & 6 & $54.5 \%$ & 39 & $86.7 \%$ & 45 & $80.4 \%$ & & & \\
\hline & Positive & 17 & $21.3 \%$ & 6 & $25.0 \%$ & 5 & $45.5 \%$ & 6 & $13.3 \%$ & 11 & $19.6 \%$ & 0.26 & 0.057 & 0.57 \\
\hline \multirow{2}{*}{$\begin{array}{l}\text { Radio- } \\
\text { therapy }\end{array}$} & No & 68 & $60.2 \%$ & 31 & $60.8 \%$ & 30 & $71.4 \%$ & 7 & $35.0 \%$ & 37 & $59.7 \%$ & & & \\
\hline & Yes & 45 & $39.8 \%$ & 20 & $39.2 \%$ & 12 & $28.6 \%$ & 13 & $65.0 \%$ & 25 & $40.3 \%$ & 0.38 & 0.023 & 1.0 \\
\hline \multirow{2}{*}{$\begin{array}{l}\text { Chemo- } \\
\text { therapy }\end{array}$} & No & 93 & $82.3 \%$ & 51 & $100 \%$ & 32 & $76.2 \%$ & 10 & $50.0 \%$ & 42 & $67.7 \%$ & & & \\
\hline & Yes & 20 & $17.7 \%$ & 0 & $0 \%$ & 10 & $23.8 \%$ & 10 & $50.0 \%$ & 20 & $32.3 \%$ & $<0.001$ & $<0.001$ & $<0.001$ \\
\hline \multirow{2}{*}{$\begin{array}{l}\text { Endo- } \\
\text { crine } \\
\text { therapy }\end{array}$} & No & 62 & $54.9 \%$ & 26 & $51.0 \%$ & 28 & $66.7 \%$ & 8 & $40.0 \%$ & 38 & $58.1 \%$ & & & \\
\hline & Yes & 51 & $45.1 \%$ & 25 & $49.0 \%$ & 14 & $33.3 \%$ & 12 & $60.0 \%$ & 26 & $41.9 \%$ & 0.14 & 0.11 & 0.57 \\
\hline \multirow{2}{*}{$\begin{array}{l}\text { Tamoxi- } \\
\text { fen }\end{array}$} & No & 74 & $65.5 \%$ & 27 & $52.9 \%$ & 32 & $43.2 \%$ & 15 & $20.3 \%$ & 47 & $75.8 \%$ & & & \\
\hline & Yes & 39 & $34.5 \%$ & 24 & $47.1 \%$ & 10 & $23.8 \%$ & 5 & $25.0 \%$ & 15 & $24.2 \%$ & 0.030 & 0.039 & 0.017 \\
\hline \multirow{2}{*}{$\begin{array}{l}\text { Aroma- } \\
\text { tase in- } \\
\text { hibitor }\end{array}$} & No & 97 & $86.6 \%$ & 49 & $98.0 \%$ & 37 & $88.1 \%$ & 11 & $55.0 \%$ & 48 & $77.4 \%$ & & & \\
\hline & Yes & 15 & $13.4 \%$ & 1 & $2.0 \%$ & 5 & $11.9 \%$ & 9 & $45.0 \%$ & 14 & $22.6 \%$ & 0.089 & $<0.001$ & 0.001 \\
\hline \multirow{2}{*}{$\begin{array}{l}\text { Trastuz- } \\
\text { umab }\end{array}$} & No & 103 & $91.2 \%$ & 51 & $100 \%$ & 35 & $83.3 \%$ & 17 & $85.0 \%$ & 52 & $83.9 \%$ & & & \\
\hline & Yes & 10 & $8.8 \%$ & 0 & $0 \%$ & 7 & $16.7 \%$ & 3 & $15.0 \%$ & 10 & $16.1 \%$ & 0.003 & 0.011 & 0.002 \\
\hline
\end{tabular}

* Grade is given either as Nottingham histological grade for invasive cancer or nuclear grade for DCIS according to CAP guidelines

College of American Pathologists (CAP) protocols [14,15] 2013 updates (3.2.0.0) available at www.cap.org. ER and PR status were available from routine pathology for all samples using antibodies NCL-ER-6F11 (Novocastra Laboratories, UK) and PgR 636 M3569 (DAKO, Hamburg, Germany) for ER and PR, respectively. HER2 immunohistochemistry (IHC) was performed using rabbit monoclonal antibody SP3 (Cell Marque Co., Rocklin, CA). A surrogate of the molecular subtypes of breast cancer was defined based on receptor status combinations according to the following groups: TNBC (triple negative), HER2-like (ER negative/HER2 positive), Luminal (ER positive/HER2 negative), and Luminal-
HER2 (ER positive/HER2 positive) $[13,16,17]$. All assessments were made blinded with respect to clinical patient data.

\section{Detection of disseminated tumor cells in bone marrow}

Disseminated tumor cell (DTC) detection was performed according to a validated immunocytochemical assay with anti-cytokeratin (CK) antibodies A45-B/B3 (AS Diagnostics, Germany) and AE1/AE3 (Chemicon by Millipore, USA) as described [18].

\section{Statistical analysis}

$\mathrm{X}^{2}$ and Fisher's Exact Test were used to determine significance of categorical variables. All p-values are two-sided and 0.05 was 
Table 3 Comparison of tumor cell dissemination with age and receptor status.

\begin{tabular}{|c|c|c|c|c|c|c|c|c|}
\hline \multicolumn{2}{|l|}{ Parameter } & \multicolumn{2}{|c|}{ Total } & \multicolumn{2}{|c|}{ DTC negative } & \multicolumn{2}{|c|}{ DTC positive } & \multirow[t]{2}{*}{ p-value } \\
\hline Age & Age $\leq 50$ & 22 & $28.2 \%$ & 19 & $31.1 \%$ & 3 & $17.6 \%$ & \\
\hline & Age $>50$ & 56 & $71.8 \%$ & 42 & $68.9 \%$ & 14 & $82.4 \%$ & 0.37 \\
\hline \multirow[t]{2}{*}{ HER2 status } & Negative & 54 & $68.4 \%$ & 45 & $72.6 \%$ & 9 & $52.9 \%$ & \\
\hline & Positive & 25 & $31.6 \%$ & 17 & $27.4 \%$ & 8 & $47.1 \%$ & 0.15 \\
\hline \multirow[t]{2}{*}{ ER status } & Negative & 21 & $26.6 \%$ & 14 & $22.6 \%$ & 7 & $41.2 \%$ & \\
\hline & Positive & 58 & $73.4 \%$ & 48 & $77.4 \%$ & 10 & $58.8 \%$ & 0.14 \\
\hline \multirow[t]{2}{*}{ PR status } & Negative & 35 & $44.3 \%$ & 23 & $37.1 \%$ & 12 & $70.6 \%$ & \\
\hline & Positive & 44 & $55.7 \%$ & 39 & $62.9 \%$ & 5 & $29.4 \%$ & 0.026 \\
\hline \multirow[t]{4}{*}{ Molecular subtype } & TNBC & 12 & $15.2 \%$ & 9 & $14.5 \%$ & 3 & $17.6 \%$ & \\
\hline & HER2 & 9 & $11.4 \%$ & 5 & $8.1 \%$ & 4 & $23.5 \%$ & \\
\hline & Luminal & 42 & $53.2 \%$ & 36 & $58.1 \%$ & 6 & $35.3 \%$ & \\
\hline & Luminal-HER2 & 16 & $20.3 \%$ & 12 & $19.4 \%$ & 4 & $23.5 \%$ & 0.23 \\
\hline
\end{tabular}

used a significance level. Follow-up information was available for 43 patients with DCIS and 40 patients with T1a tumors. Relapse of any kind (secondary DCIS or invasive cancer) was used as an endpoint. Follow-up data for those women in whom the envisaged end point was not reached were censored as of the last follow-up date. Subjects with missing values were excluded from the analyses. A Cox proportional-hazards model was used to examine the effects of covariates on relapse free survival. The effect of each individual variable was assessed with the use of the Wald test and described by the hazard ratio, with a 95 percent confidence interval $(95 \% \mathrm{CI})$. We also constructed Kaplan-Meier curves and used the log-rank test to determine the univariate significance of the variables. All analyses were performed using SPSS Statistics Version 22 (IBM Corp.).

\section{Results}

\section{Clinical characteristics of DCIS and}

invasive breast cancer patients

We analyzed a cohort of 145 patients which underwent surgical resection for either DCIS or invasive breast cancer between January 2004 and November 2011 at the Breast Unit of the Goethe University Hospital in Frankfurt. Clinical parameters of the patients are given in $\bigcirc$ Table 1. Median age was 57 years, the majority of patients (64.8\%) had ER positive disease and only $4.8 \%$ displayed primary metastasis at diagnosis. About one third of the patients (36.6\%) were diagnosed with DCIS without invasive disease.

\section{Comparison of clinical parameters and biomarkers between DCIS and invasive breast cancers}

We first compared clinical parameters of the DCIS patients with those showing invasive breast cancer. We also included an additional comparison of patients with DCIS and the subgroup of patients with T1a invasive cancers (tumor size $\leq 5 \mathrm{~mm}$ ). As shown in $\bigcirc$ Table 2 we did not detect significant differences between patients with DCIS and invasive cancers regarding patients' age, hormone receptor and HER2 status, as well as the use of radiotherapy and endocrine therapy for adjuvant treatment. The proportion of "high nuclear grade" tumors was larger in DCIS (68.8\%) compared to tumors with high histological grade among invasive cancers (32.9\%; p < 0.001), but it should be noted that "grade" refers to different definitions in the two types of samples (nuclear grade for DCIS and Nottingham histological grade for invasive breast cancer, respectively). We also applied a simplified classification of molecular subtypes of breast cancer based on receptor status of ER and HER2 $[13,16,17]$. Using this classification we found a higher number of HER2-like cancers among T1a tumors (38.1\%) compared to both DCIS (12.5\%) and to larger invasive tumors $(8.2 \%$ for T1b-T4). In contrast the number of LuminalHER2-like (ER+/HER2+) cancers was lower in T1a tumors $(9.5 \%)$ than in DCIS (25.0\%) or T1b-T4 tumors (16.3\%). These differences were significant both for T1a tumors compared to DCIS $(p=0.041)$ and between all three groups $(p=0.010$; Table 2$)$. In patients with pure DCIS no adjuvant chemotherapy or trastuzumab treatment were used. We also compared the proportion of patients displaying tumor cell dissemination in the bone marrow at primary diagnosis. Interestingly, the frequency of DCIS with disseminated tumor cells (25.0\%) did not significantly differ from that of invasive breast cancer (19.6\%; $\mathrm{p}=0.57$ ). Despite caution should be taken because of the very small sample size in our study, this observation supports previous results of early dissemination and systemic spread already in pre-invasive disease [1821].

\section{Comparison of tumor cell dissemination with age and receptor status}

We next compared the presence of disseminated tumor cells with receptor status of ER, PR, and HER2 as well as age. Since numbers were too small in separate subgroups of patients with either DCIS or invasive cancer the analysis was performed in the complete cohort only. As given in $\bullet$ Table 3 we observed a significant association of a negative PR status with disseminated tumor cell detection (70.6 vs. 37.1\%, p=0.026; $\bigcirc$ Table 3). Associations with age, ER status, HER2 status, and molecular subtype were not significant.

Prognostic factors in DCIS and T1a invasive breast cancer We next compared the relationship of clinical parameters and biomarkers with prognosis of patients with either DCIS or invasive cancer. For homogeneity we included only invasive cases with a tumor size $\leq 5 \mathrm{~mm}$ (T1a) in this analysis. Follow-up information was available for 43 patients with DCIS and 40 patients with T1a tumors. Median follow up was 47 months and 40 months for DCIS and T1a tumors, respectively. Relapse of any kind (secondary DCIS or invasive cancer) was used as an endpoint. Table 4 shows results of univariate Cox regression analysis for relapse free survival according to different parameters. Results are presented separately for the groups of DCIS patients and 
Table 4 Univariate Cox regression of relapse free survival in DCIS and T1a breast cancer according to clinical parameters and biomarkers.

\begin{tabular}{|c|c|c|c|c|c|c|c|c|c|c|c|c|}
\hline \multirow[t]{2}{*}{ Parameter } & \multicolumn{4}{|l|}{ DCIS } & \multicolumn{4}{|l|}{ T1a } & \multicolumn{4}{|c|}{ DCIS + T1a } \\
\hline & $\begin{array}{l}\text { Num- } \\
\text { bers }\end{array}$ & HR & $95 \% \mathrm{Cl}$ & $\begin{array}{l}\mathrm{p} \text { - } \\
\text { value }\end{array}$ & $\begin{array}{l}\text { Num- } \\
\text { bers }\end{array}$ & HR & $95 \% \mathrm{Cl}$ & $\begin{array}{l}\mathrm{p} \text { - } \\
\text { value }\end{array}$ & $\begin{array}{l}\text { Num- } \\
\text { bers }\end{array}$ & HR & $95 \% \mathrm{Cl}$ & $\begin{array}{l}\mathrm{p} \text { - } \\
\text { value }\end{array}$ \\
\hline $\begin{array}{l}\text { Age }(\leq 50 \\
\text { vs. }>50)\end{array}$ & 8 vs. 34 & 0.04 & $\begin{array}{l}0- \\
4950\end{array}$ & 0.59 & 13 vs. 27 & 0.42 & $\begin{array}{l}0.05- \\
3.8\end{array}$ & 0.44 & 21 vs. 61 & 0.39 & $\begin{array}{l}0.05- \\
3.08\end{array}$ & 0.37 \\
\hline $\begin{array}{l}\text { ER (negative } \\
\text { vs. positive) }\end{array}$ & 16 vs. 27 & 7.0 & $\begin{array}{l}0.72- \\
68.3\end{array}$ & 0.094 & 20 vs. 20 & 53.1 & $\begin{array}{l}0.04- \\
8 * 10^{4}\end{array}$ & 0.28 & 36 vs. 47 & 11.4 & $\begin{array}{l}1.4- \\
91.2\end{array}$ & 0.022 \\
\hline $\begin{array}{l}\text { PR (negative } \\
\text { vs. positive) }\end{array}$ & 18 vs. 24 & 4.9 & $\begin{array}{l}0.50- \\
46.9\end{array}$ & 0.172 & 24 vs. 16 & 37.3 & $\begin{array}{l}0.01- \\
3^{*} 10^{5}\end{array}$ & 0.42 & 42 vs. 40 & 7.07 & $\begin{array}{l}0.88- \\
56.7\end{array}$ & 0.066 \\
\hline $\begin{array}{l}\text { HER2 } \\
\text { (negative vs. } \\
\text { positive) }\end{array}$ & 16 vs. 9 & 0.54 & $\begin{array}{l}0.03- \\
8.65\end{array}$ & 0.66 & 19 vs. 20 & 0.37 & $\begin{array}{l}0.04- \\
3.3\end{array}$ & 0.37 & 35 vs. 29 & 0.40 & $\begin{array}{l}0.08- \\
2.09\end{array}$ & 0.28 \\
\hline $\begin{array}{l}\text { Grade } \\
\text { (high vs. low/ } \\
\text { interm) * }\end{array}$ & 30 vs. 8 & 31.2 & $\begin{array}{l}0- \\
4 \times 10^{6}\end{array}$ & 0.57 & 7 vs. 26 & 2.6 & $\begin{array}{l}0.16- \\
42\end{array}$ & 0.50 & 37 vs. 34 & 1.65 & $\begin{array}{l}0.30- \\
9.0\end{array}$ & 0.56 \\
\hline $\begin{array}{l}\text { DTC } \\
\text { detection } \\
\text { (negative vs. } \\
\text { positive) }\end{array}$ & 14 vs. 4 & 0.004 & $\begin{array}{l}0- \\
3 \times 10^{6}\end{array}$ & 0.60 & 4 vs. 4 & n.a. & n. a. & n. a. & 18 vs. 8 & 0.01 & $\begin{array}{l}0- \\
2382\end{array}$ & 0.47 \\
\hline
\end{tabular}

* Grade is given either as Nottingham histological grade for invasive cancer or nuclear grade for DCIS according to CAP guidelines

the T1a cases, respectively, as well as for both groups combined. None of the parameters were significant in the analysis within these rather small cohorts of DCIS and T1a tumors. However, we detected a trend for negative ER status (HR 7.0, 95\% CI 0.072$68.3 ; \mathrm{p}=0.094$ for DCIS, and HR 53.1, 95\% CI $0.04-8 \times 10^{4}$; $\mathrm{p}=0.28$ for $\mathrm{T} 1 \mathrm{a}$, respectively) which became significant in the combined cohort (HR 11.4, 95\% CI 1.4-91; p=0.022). Also for PR a trend was observed in the combined cohort (HR 7.1, 95\% CI $0.88-57 ; \mathrm{p}=0.066$ ). We additionally studied these two parameters in Kaplan-Meier-analysis as shown in $\bullet$ Fig. 1. Here the logrank test was applied resulting in a significant difference in survival for ER in the group of patients with T1a tumors ( $p=0.046$; - Fig. 1 b) and in the combined cohort ( $p=0.004$; 0 Fig. 1 c) and a strong trend for patients with DCIS ( $p=0.053$; $~$ Fig. $1 \mathrm{a}$ ). PR showed a significant difference in the combined cohort $(\mathrm{p}=0.032$; Fig. 1f) and a small trend for DCIS ( $p=0.13$; ○ig. $1 \mathrm{~d}$ ) and T1a ( $\mathrm{p}=0.17$; $\odot$ Fig. 1 e) patient subgroups.

\section{Discussion \\ $\nabla$}

In the present study we obtained markedly similar characteristics when comparing a cohort of patients with either DCIS or invasive cancer. A strength of our study is the use of pure DCIS as selection criteria in contrast to many analyses which failed to distinguish DCIS with (or in the presence of) invasive carcinoma from cases of pure DCIS [3] as well as the inclusion of only very small invasive breast cancer in the comparison of prognosis. Limitations however include the retrospective design of the analysis and the small sample size. It should be noted that many comparisons are clearly underpowered. Therefore our inability to detect significant differences should not be taken as indication that there are none when sample size is increased. On the other hand similarity between DCIS and invasive breast cancer has already been reported. Especially synchronous and metachronous invasive cancer harbor similar genetic aberrations as found in the DCIS [4]. Grade and ER status was also associated between index DCIS and secondary cancer in a comparison of 150 secondary breast cancers from 2636 patients with DCIS [22]. Theories of progression from DCIS to IBC mainly focus either on acquired behaviour e.g. through clonal selection or on non-genetic mechanisms e.g. driven by microenvironment [4]. Several gene expression profiling studies have demonstrated remarkably similar gene expression patterns between premalignant, preinvasive and invasive breast cancer [23-27] suggesting that progression from in situ to invasive disease is not necessarily driven by specific redundant genetic aberrations in DCIS cells [4]. More complex branched models of evolution may be much closer to reality with multiple mutational events driving multiple routes to invasive cancer $[3,4,26]$. Consequently the clarification of driving events will be complicated but emerging technologies could hint to the design of future studies [4]. One interesting aspect of our comparison between patients with DCIS and invasive cancer refers to the observation that no significant difference was found regarding the detection of disseminated tumor cells. This result seems counterintuitive and sample size is again an issue here. But beside potential technical and statistical issues similar data have been obtained before $[18-21,28]$ suggesting that profound but undetectable dissemination may occur very early.

Our results also hint towards a better prognosis of luminal type tumors both in DCIS and invasive breast cancer. In a recent systematic review [29] several previous studies were assembled which have analyzed the relationship of ER expression in DCIS and recurrence. Four of 16 studies reported a positive prognostic value of ER status. However, heterogeneity between studies and methods was rather large and no prospective studies are available. It is also not clear whether observed effects are mainly based on pure prognosis or a predictive value of ER for response to endocrine therapy. Sample sizes in subgroups of treatment are small (e.g. in our study only one quarter of the patients did not receive endocrine treatment) and numbers of events are low. One of the largest studies performed a nested case-control study based on 324 relapses among 1162 DCIS patients without endocrine treatment [30]. Negative ER status and positive HER2 status were associated with a higher risk in that study. A report applying an immunohistochemical (IHC) surrogate to define the basallike subgroup among 392 DCIS observed a non-significant trend for higher recurrence [31]. In a presentation at the San Antonio 

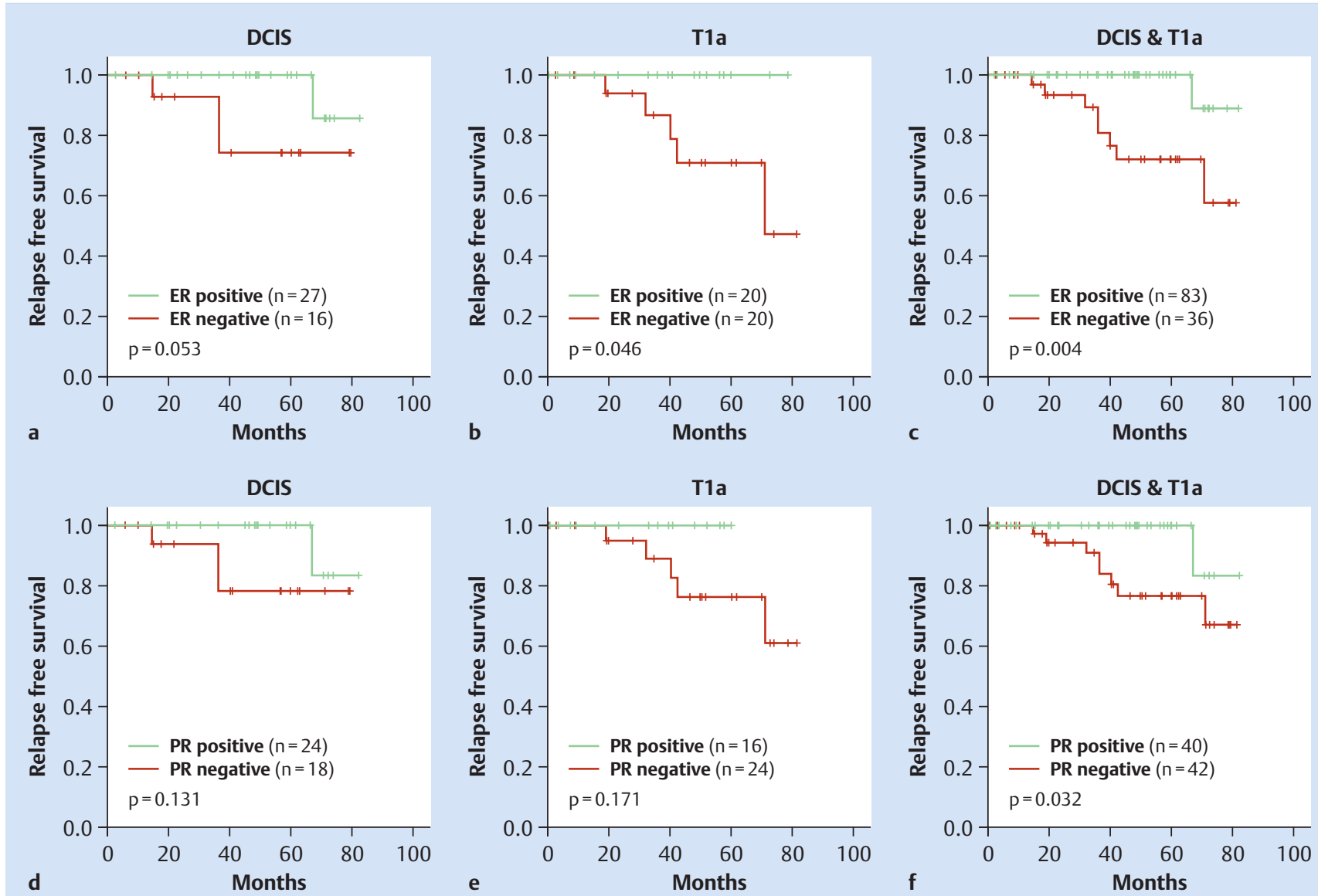

Fig. $1 \mathrm{a}$ to $\mathbf{f}$ Prognosis of DCIS and T1a invasive breast cancer according to hormone receptor status. Kaplan-Meier analysis of relapse free survival according to ER status $(\mathbf{a}, \mathbf{b}, \mathbf{c})$ and PR status $(\mathbf{d}, \mathbf{e}, \mathbf{f})$ are presented for DCIS

cases (a, d), T1a invasive breast cancers (b, e), and the combined cohorts (c, f). Any relapse (secondary DCIS or invasive cancer) was used as endpoint. $\mathrm{P}$-values from log-rank test are given.

Breast Cancer Symposium 2012 the same approach we used for IHC molecular subtype surrogates was applied to categorize 314 patients with DCIS [13]. The frequencies of the respective subtypes were similar to our analysis (given in parentheses): $42.4 \%$ Luminal (43.8\%), 28.0\% Luminal-HER2 (25.0\%), 15.9\% HER2 (12.5\%), and $13.7 \%$ TNBC (18.8\%). A good prognosis was detected mainly for the Luminal subgroup (hazard ratios $>14$ compared to the other groups; $\mathrm{p}<0.02$ ). When we analyzed all subtypes separately in our cohort samples size in the individual groups was very small and the prognostic effect did not exceed that of ER status alone (not shown). Nevertheless, other researchers also reported an increased risk of recurrence in the HER2-like and Luminal-HER2 groups [32]. Taken together, since IHC surrogates are readily available they represent an attractive pragmatic approach for studies on risk assessment of molecular subtypes of DCIS [1]. Clearly validation datasets are needed to establish whether this marker panel could replace traditional risk factors or be amalgamated into a model or nomogram.

\section{Conclusions for Practice}

Despite effective therapy many patients with DCIS are either over- or undertreated because of the paucity of precise models to predict recurrence or progression. The combination of clinical and molecular factors may help to build such models. A luminal phenotype seems to be characterized by a favourable prognosis but needs to be validated in further studies.

\section{Acknowledgements}

We thank Katerina Brinkmann and Samira Adel for expert technical assistance. This work was supported by grants from the H.W. \& J. Hector-Stiftung, Mannheim; the Margarete Bonifer-Stiftung, Bad Soden; National Cancer Center, New York; and the BANSSStiftung, Biedenkopf.

\section{Conflict of Interest \\ $\nabla$}

None.

\section{References}

1 Benson JR, Wishart GC. Predictors of recurrence for ductal carcinoma in situ after breast-conserving surgery. Lancet Oncol 2013; 14: e348e357

2 Heywang-Koebrunner S, Bock K, Heindel $W$ et al. Mammography screening - as of 2013. Geburtsh Frauenheilk 2013; 73: 1007-1016

3 Bartlett JMS, Nofech-Moses S, Rakovitch E. Ductal carcinoma in situ of the breast: can biomarkers improve current management? Clin Chem 2014; 60: 60-67 
4 Cowell CF, Weigelt B, Sakr RA et al. Progression from ductal carcinoma in situ to invasive breast cancer: revisited. Mol Oncol 2013; 7: 859-869

5 Fasching PA, Ekici AB, Wachter DL et al. Breast cancer risk - from genetics to molecular understanding of pathogenesis. Geburtsh Frauenheilk 2013; 73: 1228-1235

6 Solin LJ, Gray R, Baehner FL et al. A multigene expression assay to predict local recurrence risk for ductal carcinoma in situ of the breast. J Natl Cancer Inst 2013; 105: 701-710

7 Reis-Filho JS, Pusztai L. Gene expression profiling in breast cancer: classification, prognostication, and prediction. Lancet 2011; 378: 18121823

8 Goldhirsch A, Wood WC, Coates AS et al. Strategies for subtypes-dealing with the diversity of breast cancer: highlights of the St Gallen International Expert Consensus on the Primary Therapy of Early Breast Cancer 2011. Ann Oncol 2011; 22: 1736-1747

9 Prat A, Ellis MJ, Perou CM. Practical implications of gene-expressionbased assays for breast oncologists. Nat Rev Clin Oncol 2011; 9: 48-57

10 Koboldt DC, Fulton RS, McLellan MD et al. Comprehensive molecular portraits of human breast tumours. Nature 2012; 490: 61-70

11 Karn T. High-throughput gene expression and mutation profiling: current methods and future perspectives. Breast Care (Basel) 2013; 8: 401-406

12 Clark SE, Warwick J, Carpenter $R$ et al. Molecular subtyping of DCIS: heterogeneity of breast cancer reflected in pre-invasive disease. $\mathrm{Br}$ J Cancer 2011; 104: 120-127

13 Williams KE, Barnes NL, Cheema K et al. Molecular phenotypes of DCIS predict invasive and DCIS recurrence. 35th Annual San Antonio Breast Cancer Symposium. PD04-06, San Antonio, TX; 2012

14 Lester SC, Bose S, Chen Yet al. Protocol for the examination of specimens from patients with invasive carcinoma of the breast. Arch Pathol Lab Med 2009; 133: 1515-1538

15 Lester SC, Bose S, Chen Yet al. Protocol for the examination of specimens from patients with ductal carcinoma in situ of the breast. Arch Pathol Lab Med 2009; 133: 15-25

16 Hugh J, Hanson J, Cheang MCU et al. Breast cancer subtypes and response to docetaxel in node-positive breast cancer: use of an immunohistochemical definition in the BCIRG 001 trial. J Clin Oncol 2009; 27: 1168-1176

17 Goldhirsch A, Wood WC, Coates AS et al. Strategies for subtypes-dealing with the diversity of breast cancer: highlights of the St Gallen International Expert Consensus on the Primary Therapy of Early Breast Cancer 2011. Ann Oncol 2011; 22: 1736-1747

18 Sänger N, Effenberger KE, Riethdorf S et al. Disseminated tumor cells in the bone marrow of patients with ductal carcinoma in situ. Int J Cancer 2011; 129: 2522-2526
19 Hüsemann Y, Geigl JB, Schubert F et al. Systemic spread is an early step in breast cancer. Cancer Cell 2008; 13: 58-68

20 Banys M, Gruber I, Krawczyk $N$ et al. Hematogenous and lymphatic tumor cell dissemination may be detected in patients diagnosed with ductal carcinoma in situ of the breast. Breast Cancer Res Treat 2012; 131: 801-808

21 Banys M, Hahn M, Gruber I et al. Detection and clinical relevance of hematogenous tumor cell dissemination in patients with ductal carcinoma in situ. Breast Cancer Res Treat 2014; 144: 531-538

22 Arvold ND, Punglia RS, Hughes ME et al. Pathologic characteristics of second breast cancers after breast conservation for ductal carcinoma in situ. Cancer 2012; 118: 6022-6030

23 Ma X, Salunga R, Tuggle JT et al. Gene expression profiles of human breast cancer progression. Proc Natl Acad Sci U S A 2003; 100: 59745979

24 Schuetz CS, Bonin M, Clare SE et al. Progression-specific genes identified by expression profiling of matched ductal carcinomas in situ and invasive breast tumors, combining laser capture microdissection and oligonucleotide microarray analysis. Cancer Res 2006; 66: 5278-5286

25 Vincent-Salomon A, Lucchesi C, Gruel $N$ et al. Integrated genomic and transcriptomic analysis of ductal carcinoma in situ of the breast. Clin Cancer Res 2008; 14: 1956-1965

26 Allred DC, Wu Y, Mao S et al. Ductal carcinoma in situ and the emergence of diversity during breast cancer evolution. Clin Cancer Res 2008; $14: 370-378$

27 Muggerud AA, Hallett M, Johnsen $H$ et al. Molecular diversity in ductal carcinoma in situ (DCIS) and early invasive breast cancer. Mol Oncol 2010; 4: 357-368

28 Stoecklein NH, Klein CA. Genetic disparity between primary tumours, disseminated tumour cells, and manifest metastasis. Int J Cancer 2010; 126: 589-598

29 Lari SA, Kuerer HM. Biological markers in DCIS and risk of breast recurrence: a systematic review. J Cancer 2011; 2: 232-261

30 Kerlikowske K, Molinaro AM, Gauthier ML et al. Biomarker expression and risk of subsequent tumors after initial ductal carcinoma in situ diagnosis. J Natl Cancer Inst 2010; 102: 627-637

31 Zhou W, Jirström K, Johansson C et al. Long-term survival of women with basal-like ductal carcinoma in situ of the breast: a populationbased cohort study. BMC Cancer 2010; 10: 653

32 Han K, Nofech-Mozes S, Narod S et al. Expression of HER2neu in ductal carcinoma in situ is associated with local recurrence. Clin Oncol ( $\mathrm{R}$ Coll Radiol) 2012; 24: 183-189 